\title{
RUSSIAN ADMINISTRATIVE REFORM: BETTER OUTCOMES THROUGH BROADER PARTICIPATION ${ }^{1}$
}

\author{
Alexander Yu. Sungurov \\ Dr., Ph.D. in Political Science, Professor of the National \\ Research University Higher School of Economics (St.-Petersburg). \\ Address: 123 Griboedova Ch. Embankment, \\ 190068, Saint Petersburg, Russian Federation. \\ E-mail: asungurov@mail.ru

\section{Daniil K. Tiniakov} \\ Post-graduate student of Political Science at the National \\ Research University Higher School of Economics (St.-Petersburg). \\ Address: 15 -15, 1st Murinski Av., \\ 194100, Saint Petersburg, Russian Federation. \\ E-mail: tinyakovdk@gmail.com
}

\begin{abstract}
The following paper deals with the issue of the Russian administrative reform of the 2000s. The subject of analysis is the relationship between the extent of inclusivity in the reform process and its outcomes. To study this relationship we start by focusing on the federal stage of the reform's design, outlining institutions, involved actors and their strategies. We claim that due to the closed nature of the reform, its official Conception was highly incoherent. Following this, we turn our attention to the implementation of the reform in the Russian regions. We illustrate this process by outlining one case of the reform in the Republic of Karelia, based on interviews with representatives of bureaucracy, civil society and the expert community. Here we also demonstrate that greater engagement by interested groups results in better implementation of reform. Then we introduce simple regression to trace the relationship between two major directions of administrative reform - one based on the new public management idea of cost efficiency and the other grounded in the public governance call for greater community participation. Our model shows that these directions are hugely contradictory due to the logical incoherent Conception of the reform. We suggest some possible solutions to deal with this problem to some extent, which will require an even broader set of actors involved in the reform process. Therefore, looking at examples from the federal and regional dimensions of the Russian administrative reform, we argue that a more open regime within a policy subsystem with a broader circle of participating actors will lead to a more coherent content of policy change and better implementation of the initial conception.
\end{abstract}

\footnotetext{
1 The paper was prepared within the framework of the Academic Fund Program at the National Research University Higher School of Economics (HSE) in 2016 (grant N 16-05-0059) and supported within the framework of a subsidy granted to the HSE by the Government of the Russian Federation for the implementation of the Global Competitiveness Program.
} 
Keywords: administrative reform; Russian administrative reform; participation in reform process; regional level of administrative reform; administrative paradigms; federal conception of the administrative reform.

Citation: Sungurov, A.Yu. \& Tiniakov, D.K. (2018). Russian Administrative Reform: Better Outcomes through Broader Participation. Public Administration Issues, Special Issue (electronic edition), pp. 133-144 (in English); DOI: 10.17323/1999-5431-2018-0-5-133-144.

$\mathrm{R}$ ussian administrative reform has been ongoing since the early 2000 s. Even in the 1990s, there were some attempts to design changes in the public administration system (Krasnov, Obolonsky, 2003). Despite its rather long implementation, the reform is far from over. Moreover, its outcomes can be described as disputable. There are some relatively important steps toward modernization of the bureaucratic process: e.g., a more precise and unified regulation of services, the introduction of multifunctional centers of public services and e-government mechanisms, and realization of the service function of public officials in relation to citizens. At the same time, a lot of other no less (or perhaps even more) significant initial aspects of a probable reform were greatly reduced: the functional reorganization of the administrative system, broader inclusion of civil society in decision-making and appraisal processes, lesser administrative borders for the economy etc. In what follows, we show that this pale outcome of the reform is in large part explained by the character of the reform process. We argue that the closed regime of policy management within an administrative subsystem with a restricted set of participants made the design of the reform logically inconsistent and its implementation far from satisfactory. On the other hand, engagement by different interested actors and group of actors could lead, and did lead in some instances, to more coherent and deliberated design and more successful implementation of and/or change in policy.

This statement echoes some ideas from both the political philosophy and theory and the modern trends of the public administration studies. In political philosophy, the claim of normative good from broader engagement of the public in political life, not only as voters but also as active participants, stems from the works of J. Habermas (Habermas, 1984; Habermas, 1987) and J. Rawls (Rawls, 1997). These thinkers expressed the ideas that wider participation in communication and use of reasoning during it could lead to more consensual, fair and legitimate decisions. Later these philosophical foundations were developed to the more elaborated theory of deliberative democracy. In public administration studies and practices, these normative premises resulted in the relatively recent ideas of the new public governance approach and the even more recent mid-range and micro theories and techniques describing ways for community inclusion and dealing with some of the practical and theoretical problems around this issue. Working in this tradition, S. Osborne developed the co-production theory. His recent theoretical study on this subject (Osborne et al., 2016) is based on the new public governance approach, system theory and service management theory. In combining the premises of these ideas, Osborne comes to some important conclusions: a) there is always a co-production of a result of a public services process from both sides ('producer' and 'consumer') whether it is voluntary and/or conscious or not; $b$ ) the result of a public service process affects not only the 
immediate consumer but also his significant others, a broader circle of the community and even the whole social system in the potential future; c) the depth and breadth of the effect of public service co-production depends on the extent of consciousness and willingness of both sides to invite (or be invited) and accept the participation of a 'consumer' in the process. Therefore, we see that the inclusion of 'consumers' in the process of public service production has the potential to change the quality of a given service and even to affect the frames of a whole system. In spite of this, Osborne also reminds us that co-production of services may result not only in co-creation of public value, but also in co-destruction of it. Another popular direction of research in public administration studies is the work on concept of participatory government. This idea draws upon the same normative belief that deliberative approaches result in better decisions than alternative ways and suggests some instruments that allow for including (to different extent) the 'ordinary' public into the deliberation process: e.g., focus groups, televoting, consensus conferences, citizens jury etc. (Fisher, 2012). Studies show that preliminary broad deliberation could potentially change the initial policy views of decision-makers (Burgess, 2014) and lead to more objective, critical, representative and legitimate decisions (Brown, Dillard, 2015). These authors also note that there are some prerequisites for useful deliberation (the most important are actual and full information through proper means of accounting (Brown, Dillard, 2015) and readiness of decision-makers to outline possible choices and change their policy directions (Burgess, 2014). There are also some significant questions to the concept of a participatory government that need to be resolved in future studies. E.g., deliberative procedures could legitimate decisions without actually affecting it; participants with the status of experts could both provide some important information and restrict the opinions of others through their authority (Burgess, 2014); the manner in which the 'public' is defined (and who defines it) may also influence results and the effect of deliberative processes (Brown, Dillard, 2015). Nevertheless, we can sum up that generally in modern public administration studies (based on earlier philosophical ideas) it is acknowledged that broader participation of different types of stakeholders in decision-making and preliminary deliberation may cause an actual effect on results of policy process in terms of its quality, legitimacy, fairness etc.

As we said earlier, in the given work we claim that broader participation of different types of actors in the Russian administrative reform process had the potential for better outcomes of the reform. We support this suggestion with our analysis of the design of the initial conception of the reform at the federal level. Then it is illustrated with the case of the administrative reform in the Republic of Karelia. In addition, we end up with statistical evidence of existing negative effects of logical incoherence on the implementation in regions.

\section{Design of Federal Conception}

We start our analysis by sketching the work on reform conception and the instruments of implementation control that was undertaken on a federal level of authority. But firstly we need to clarify what we mean by the notion of management regime of policy subsystem. In general, we can define this term as a combination of institutions and actors, their strategies, resources, practices, that exists in a given 
policy subsystem ${ }^{2}$ and whose actions and decisions are oriented and empowered to form this policy, i.e. to design and implement policy change. Here one can easily detect a similarity with the notion of political regime (Bri M., Gel'man V., Ryzhenkov S., 2000, pp. 12-20) accepted in new institutional theory. Some common moments could be traced with a concept of a political-administrative regime, that includes "the real way of authority functioning, its shape and style of realization" (Blinova, 2009, p. 4). One important difference is that these notions of political and political-administrative regimes are bounded with some piece of territory for which they are relevant. For our concept, the borders of the policy subsystem are more significant, though territorial boundaries could be significant also.

The institutional structure of the process of reform's conception on the federal level is rather simple. The reform's design was the task of the special Committee. The President of the administrative reform committee (a high-ranked ministerial official at the level of vice-prime minister or close to it) made the final decision. The President of the Committee himself did not participate actively in the very process of deliberation; he rather played the role of a referee in a dispute between supporters of different alternative visions of the reform (often trying to reach a compromise, needed or not). The whole process was hidden from the public; all decisions were made inside the body of executive authorities. Formally, there was an opportunity to invite some external experts to the process of the reform's design (in spite of this, invited experts were never unaffiliated with nor independent from disputing parties within the Committee).

The analysis of the actors' constellation and their strategies is a slightly more difficult task. We already mentioned that there were some groups who advocated for different alternatives. According to the President of the Center for Strategic Research (CSR - the expert organization strongly affiliated with the Department of Economic Development), M. Dmitriev, these groups could be tentatively divided into 1) the supporters of liberal ideas coming from new public management and public governance approaches, and 2) 'statist' bureaucrats unwilling to radically change themselves (Administrativnaya reforma, 2011). In the beginning of 2000s, groups had a rather equal influence on the policymaking process: technical (liberal in economic sense) reformers were needed to implement the Russian modernization project, conservative 'siloviki' and statist bureaucrats had personal bounds with the highest layer of authority, they were one of the reference groups for currently shaping the regime of electoral authoritarianism (Gel'man, Starodubtsev, 2014). From the neo-institutional perspective of rational choice, we would expect the same interests for both groups: as soon as they consist of public servants and very closely related experts (often also former state officials), their priority is saving or enhancing their position in hierarchy. In almost every change to the public administration system, its familiar formal and informal rules would impose some costs for bureaucrats. This is especially the case with reforms inspired by new public management's idea of economic efficiency and public governance's call for the broad participation of civil society (Osborne, 2006.) An argument among bureaucrats with, as expected, the same rational interests could be explained with the help of other concepts. P. Sabatier

\footnotetext{
2 The concept of policy subsystems is elaborated in works of P. Sabatier (Sabatier, 2007, p. 189-220).
} 
suggests that besides material interests, even more important for participants of the policy-making process are their "deep core beliefs" about policy content. Around these beliefs advocacy coalitions are built to support one of the existing policy alternatives (Sabatier, 2007, p. 189-220). In our case, we cannot strongly claim the presence of such coalitions: they do not meet some of Sabatier's criteria, especially, the one about diversity of participants. However, we can assume that opposing groups within the administrative reform process were driven by these deep-seated beliefs. One - by the technocratic idea of the benefit of free-market features (competition, openness) for public administration performance. Another - by the conservative vision of the strict and almost militaristic hierarchical system of the old bureaucracies (with a little space for change or no need for it at all).

After a description of the set of advocacy groups acting in the arena of public administration policy we should depict their possible strategies and actual actions to see what they did and - in context of our work and much more importantly what they could do to fulfill their views of a good administrative system.

To describe the set of strategies and tactics of actors we transfer some ideas of B. Latour about the strategies and tactics of scholars in creating a new scientific fact. (Latour, 1987). He portrayed the process of scientific knowledge emergence as the construction of a black box by scholars. At the start, there is no common understanding of the nature of things; different scholars could advocate alternative views and theories of a given phenomenon. Their aim is to make their point of view the only one acceptable by everyone (or almost everyone). To do this, their foremost strategy is to make alliances with actors of both human nature and non-human nature (former knowledge, experiments, experience etc.). Latour also gives concrete examples of tactics used by actors to strengthen their positions in the struggle for powerful allies:

1. "I want what you want" - presentation of ideas as if they corresponded to the explicit interests of a target audience;

2. "I want it, why don't you?" - relevant actors have no other way of meeting their needs than to follow proposed ideas;

3. "If you just make a short detour..." - persuasion of potential allies, that the best (shortest, cheapest etc.) way to achieve their interests is to support the opinion of reformers (scholars);

4. "Reshuffling interests and goals" - displacing, mixing and changing goals of the target actors, hiding other ways to achieve their aims, finding new relevant groups to make them follow reformers' ideas;

5. "Becoming indispensable" - construction of the network of allies (both of human and non-human nature: instruments, research results, past and foreign experience etc.) around some concepts to leave newcomers with no other choice other than to follow these ideas. Actually, this strategy is being used during the last stages - when most of the bonds are already established and the "black box" is nearly closed (Latour, 1987, pp. 108-121).

We can make some kind of analogy with a process of reform. In the beginning, there are a lot of alternatives and their supporters are relatively weak towards each other. Later, struggling parties, through the skillful (or not) use of different tactics, increase the extent of their influence. We can imagine that actors could strengthen 
themselves with some personal connections and the support of professional or civil communities and organizations (experts, mass media, NGOs etc.) In addition, they can use prior or foreign experience and the early results of their activity to prove their rightness. Moreover, once their influence is strong enough, their ideas are implemented in practice and become a fact of the current social reality.

During the preliminary stage of the work on the possible change of administrative system, reformers used mostly the first two of the tactics described above. They tried to comply their suggestions with the current interests of the political elite. However, due to changes in government structure, the financial problems of 1998 and a lack of political will for change, the work on the reform stopped (interview with V. Smirnov - one of the members of the expert working group, St.-Petersburg, 2012). We suppose that such a situation could be different if the reformers used a broader set of tactics and made broader alliances including with the public.

At the beginning of the 2000s, the reformers implemented a "detour" tactic. Experts from the CSR invited by the Department of Economy reduced the clumsy and unclear problem of state (re-)building to the simpler (and more understandable for the elite) task of administrative reform (Sungurov, Tinyakov, 2016, p. 42-43). This "detour" attracted attention and enabled the formal creation of the federal Administrative Reform Committee and later the official Conception of the Administrative Reform.

Despite this 'trick' being quite successful, we cannot say the same thing about the later actions of the reformers. The work on the Conception of the Reform is actually one instance of the unskillful use of the 'reshuffling interest' tactics by the ideologists of policy change. They could not bind the existing interests of the political elite with their mostly liberal ideas of economic efficiency, bureaucracy and society inclusion. The process of reform design was tightly shielded from publicity and external experts (Barabashev, 2003, p. 174, 179, 209). The issue of changes to the bureaucratic system was not included in the media agenda. However, the possible allies from the expert community, civil society and people in general (with the help of the mass media) could strengthen the positions of reformers significantly, making politicians follow their ideas. Despite some attempts to include representatives of the expert community and civil society, they were highly limited on one hand, and activists were not fully ready to participate on the other. Besides, the reformers' program was not sufficiently supported by allies of a 'non-human nature': early experiences, international practices, and exciting concepts from public administration theory. For example, the Head of the CSR, M. Dmitriev, did not even know about previous reform attempts in 1990s (Sungurov, Tinyakov, 2016, p. 44). The very content of suggestions from CSR experts is incoherent to some extent: many components of the reform were included ad hoc; the Conception itself was a mix of outdating new public management concepts and modern public governance theory (Osborne, 2007). All these failures made it impossible to acquire the full support from politicians (namely the president and prime minister) for the suggested reform project.

In the same time, opposing groups from the conservative part of the federal bureaucracy and regional bureaucracies were formed. These groups were slightly more successful in their manipulation of officials' interests to realize their own (as less uncomfortable changes as possible). They emphasized the lack of finances 
and need for strong state control which resulted in reducing some aspects of the suggested reform, e.g., deregulation of the economy, public participation and extension of public administration transparency. Under the influence of the conservative 'siloviki', an almost military hierarchy of civil service was adopted (Interview with M. Dmitriev, Moscow, 2013).

Though we showed that there was a slight difference in how successful the interests of opposing groups were mixed and complied with those of the political elite, we must note that neither group made strong enough alliances with actors of 'human nature. Neither liberal reformers nor their conservative counterparts invited external experts to the deliberative process or organized significant public support of their positions. In terms of P. Sabatier we can conclude that neither group created an advocacy coalition in the full meaning of this concept. The result was a compromise version of the reform conception where a lot of the initial ideas of reformers were included but in a trimmed version. Therefore, the structure of the actors and their strategies on the federal level of the design process made the content of the reform logically incoherent from the very start. In other words, we can claim that in this case 1) a more inclusive management regime in a given policy subsystem would make the conception of the reform more consistent, and 2 ) the engagement of a broader set of actors would facilitate the initial ideas of reformers (given that the community is interested in their implementation).

\section{Administrative Reform in the Republic of Karelia}

The benefits from expansion of the circle of reform participants on a regional level can be illustrated with a case of changes in the administrative system in the Republic of Karelia (one of Russia's regions). From the beginning of the regional stage of the administrative reform, Karelia was one of leaders of its implementation (Kulakova, 2009). Since the end of the 2000s, the reform dynamics have slowed down and the issue almost vanished from the official agenda.

Our respondents - public officials and representatives from the expert community and civil society - connected this trend with the replacement of the former Head of the Republic (a man of local origin, S. Katanandov) by the federal appointees. There was a system of close and often informal bounds with the local community during Katanandov's term in office: "our own small polity" (Interview with O. Reut, Petrozavodsk, 2013), "all of us use informal contacts, of course" (Interview with E. Tsumarova, Petrozavodsk, 2013), "my student became the Head of the Republic - Katanandov Segei Leonidovich" (Interview with A. Shishkin, Petrozavodsk, 2013). According to respondents, these linkages with the community contributed to vivid discussions with the engagement of a broad circle of local experts (from business and scientific circles and civil society), which activated and facilitated the reform process in its early stage. The appointment of those from other regions to the position of the Head of the Republic coincides timewise with the slowdown of changes in the administrative subsystem. Ties with the community were broken, the reform became locked within bureaucracy and reduced to some formal components, and gradually came to naught: "artificiality, inadaptability [of changes]" (Interview with O. Reut), "replacement of terms of civil society 
to e-democracy $\{\ldots\}$ They found $\{\ldots\}$ an aspect that they understand how to do" (Interview with E. Tsumarova).

This example shows that in a regional dimension also, a more inclusive management regime within one policy can foster the implementation of a reform. The consequences of the logical inconsistency of a mixed and compromised Conception of the Administrative reform for its implementation can be traced by looking at the situation in a cross-regional perspective with some help from quantitative methods.

\section{New Public Management vs. Public Governance in Russian Regions}

Before doing this let us briefly remind ourselves of the ideas behind the approaches to new public management and public governance. The former implies that a good state bureaucratic system should be regulated in the same way that the administrative apparatus of a private company is (Osborne, 2007). According to this logic, the foremost criterion of quality is economic (or even financial) efficiency. Those with the same "job description" but lesser costs are always appreciated higher. Another idea in this tradition is the budgeting oriented to the results of one's activity. The latter approach claims that good public administration should be as inclusive as possible (Osborne, 2007); the extreme point of this is the "governance without government" (Rosneau, Czempiel 1992). There is a lesser focus on finances issue, which makes this approach more flexible and versatile. The key idea here is not the economic efficiency but the orientation of the bureaucratic activity to the public good from the point of view of society (or the local community).

The final version of the official Conception of the Russian Administrative Reform is borrowed from both of these concepts. As we showed earlier, this "borrowing" was not based on any coherent framework of understanding of the administrative system. We decided to trace how regulations resulting from both traditions were reflected at the stage of regional implementation of the reform. To analyze this we built simple binary regression model representing the relationship between changes in regional political regimes and dynamics of inefficient expenditures on the functioning of regional public executives. The period of consideration began in 2008 - the full-fledged start of the reform in the regions - and ended in 2012. We included data from all the regions which existed in 2008 except those that had changed their territorial borders (a total of 79 regions).

Using a variable of inefficient expenditures, we tend to reflect the ideas of the new public management approach. Dynamics was measured as the difference between values at the end of a considered period and at the start of it. Data were collected from the official national statistical service (Rosstat) and from regional budgets. Inefficient expenditures on public administration were calculated accordingly with official formulae used by the Department of the Economy (Monitoring Yugra):

$$
E A_{\text {reg }}-\frac{E A_{\text {total }}}{E X P_{r_{\text {reg }}} \times E X P_{\text {total }} \times K},
$$

there EA stands for expenditures on the functioning of the regional government and executive branch of authority in the budget of region (reg) or as the sum of the budgets 
of all Russian regions (total); EXP stands for overall volume of regional expenditures in the budget of one region (reg) or as the sum of the budgets of all Russian regions (total); $K$ stands for coefficient of scale, which in turn is calculated as following (the smaller a region is, the more it is penalized for extra expenses; this makes a final value weighted):

$$
0,7+0,5 \times \frac{A V G \text { Population }}{R E G \text { Population }} .
$$

The dynamics of regional political regime change was also measured as the difference between values at the end of considered period and at the start of it. This variable to some extent describes the dimension of public governance. To measure this parameter, we use the rating of democracy in Russian regions designed by experts of the Russian Carnegie Center (Petrov, Titkov, 2013). Experts evaluate the annual level of democracy in Russian regions by looking at the following components: 1 . formal political arrangements; 2 . the extent to which the elections could be called democratic; 3 . level of openness of political life; 4. political pluralism; 5 . independence of media; 6 . level of corruption; 7. economic liberalization; 8 . civil society; 9. quality and changeability of elites; 10 . local (self-)governments (ibid.). Despite it being clear that not all of these components are directly related to the concept of public governance, we could see some intersection here. Moreover, some sub-parameters exactly reflect the ideas of the inclusiveness of the decision-making process $(3,4,6,8,10)$. Taking into account the lack of more precise evaluations in the context of our interest and having no task of exact operationalization, we make an assumption that more democracy means more opportunities for the public to participate in decisionmaking (not necessarily vice-versa, though). This engagement of the community is the core of the public governance approach, which makes it possible for us to use the democracy rating as a decent approximation to measure this direction of the administrative reform.

The results of the analysis are presented in a regression model with dynamics of inefficient expenditures as a dependent variable in a table below:

Table

\section{Interrelation of dynamics of inefficient public administration expenditures with changes of regime. Binary linear regression}

\begin{tabular}{|c|c|c|c|c|}
\hline \multicolumn{5}{|c|}{ Coefficients: } \\
\hline & Estimate & Std. Error & t value & $\operatorname{Pr}(>|t|)$ \\
\hline Intercept & -4.987 & 56.843 & -0.088 & 0.930321 \\
\hline Regime change & 194.848 & 54.102 & 3.601 & $0.000566^{* * *}$ \\
\hline \multicolumn{5}{|c|}{ 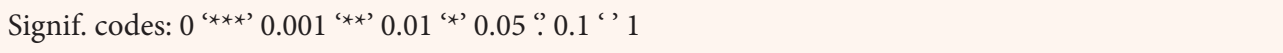 } \\
\hline $\begin{array}{l}\text { Residual standa } \\
\text { Multiple R-squa } \\
\text { F-statistic: } 12.97\end{array}$ & $\begin{array}{l}75 \text { degrees o } \\
\text { ted R-square } \\
\text {-value: } 0.00\end{array}$ & & & \\
\hline
\end{tabular}


This simple model demonstrates with a high level of statistical significance that a change in the level of democracy in Russian regions is closely related to a change in the amount of inefficient expenditures on public administration. There is a direct relationship between these variables: each point of the democracy rating improvement costs about 195 million rubles of inefficient expenditures on public administration. Substantially, this dependence could mean that democratic institutions are expensive to maintain. In the context of our interest, assuming that democracy facilitates public governance mechanisms by its definition, we can see here clearly the contradiction between the managerial and public governance components of Russian reform. That means that in Russia's case aiming for costefficiency in public administration does not correspond with the initial ideas of more participation by the public in decision-making and in the evaluation of bureaucracy activity. We cannot argue that this is true for every possible case; however, we show that to mix these paradigms with no coherent logical basis is, at the very least, useless (if not harmful).

Indirectly this contradiction is confirmed by M. Dmitriev (for the time being, one of the leading experts in the topic of the Russian administrative reform) who claims that the cost-efficiency of a process in the administrative system is inversely related to the extent of difficulty (M. Dmitriev's report on Modern trends in the Russian Administrative reform, $9^{\text {th }}$ June, 2017). Nevertheless, at the same time both features can contribute to the quality of the result if the process is not simplifiable. One of the suggested modern responses is the procedure of automatization. If the process is expensive and difficult, it cannot be simplified without a loss in the quality of its result, but it is possible to algorithmize at least some part of it, and these algorithms could often be executed without human intervention (M. Dmitriev's report, 2017). This solution has both advantages and disadvantages. On the one hand, it reduces costs and the chance of human error; on the other hand, there is less space for the discretion that is sometimes needed in individual cases. Howbeit, the procedure of automatization is a clear step toward the convergence of cost-efficiency with difficult and often costly to maintain processes of broader participation (including procedures of participatory governance and co-production of public services) and accountability.

This statement leads us to the claim that the set of actors working on reform conception and especially its implementation must be enlarged even more. The introduction of these kinds of technological innovations will require among other things trustworthy consultancy from experts in the IT and other related spheres. At the implementation stage, these types of specialists will be needed for the development of concrete software decisions. Therefore, we are again at the point where a more inclusive reform process and a more open managerial regime will support the logical cohesiveness of the reform and the quality of its implementation.

We have shown (above) the possible benefits from the broad inclusion of different types of actors at each stage of the Russian administrative reform. The initial approach of a closed bureaucratic reform designed and implemented 
inside the administrative system, by its own forces and under its own control resulted in a logically inconsistent reform conception and its even greater degeneration at the stage of implementation in the regions, where regional bureaucracies had significant discretion in their interpretation of regulations and choice of priorities. Our analysis showed that more open managerial regimes in the administrative policy subsystem would likely secure a logical base for the reform's conception and enhance the quality of its implementation. On the federal level, consistency of the reform could be achieved through more thorough deliberation due to broader participation in general and/or through the organization of public and expert support for the initial ideas of reformers (as soon as they were oriented to the public good). On the regional level, the engagement of the community would again mean deliberation that is more thorough and would impose some incentives for regional authorities to implement reform. Moreover, the drawbacks built into the official Conception resulted in the regions experiencing a contradiction between two of the theoretical sources of the reform. This problem could be at least partly solved by involving actors who are up to this point not directly connected to the sphere of public administration, namely, IT specialists. This again would mean the need for even more expansion of the circle of participants in the reform process.

\section{REFERENCES}

1. Administrativnaya reforma (2011). Interv'yu s Dmitrievym M.E. [The Administrative Reform. An Interview with Dmitriev M.E.]. Vestnik Evropy, 16 January. Available at: http:// www.vestnikevropy.com/all-articles/2011/1/16/318609816511.html (accessed: 20 December, 2017).

2. Barabashev, A.G. (2003). Popytka reformy gosudarstvennoy sluzhby 1999-2000 gg. (predlozheniya Centra strategicheskikh razrabotok) [1999-2000 Civil Service Reform attempt (Suggestions of The Center for Strategic Research]. The Civil Service Reform in Russia: History of Reform Attepmts from 1992 to 2000. Moscow: Ves' Mir, pp. 157-210.

3. Blinova, E. (2008). Kharakteristika politiko-administrativnogo rezhimma v respublike Komi. [Characteristic of the Republic of Komi Political-Administrative Regime]. Democracy and Administration, no 1, pp. 4-10.

4. Bri, M., Gel'man, V. \& Ryzhenkov, S. (eds.) (2000). Rossiya regionov [Russia of its regions]. Moscow: Ves' Mir.

5. Brown, J. \& Dillard, J. (2015). Dialogic Accountings for Stakeholders: On Opening Up and Closing Down Participatory Governance. Journal of Management Studies, vol. 52, no 7, pp. 961-985.

6. Burgess, M.M. (2014). From “Trust Us" to Participatory Governance: Deliberative Publics and Science Policy. Public Understanding of Science, vol. 23, no 1, pp. 48-52.

7. Fisher, F. (2012). Participatory Governance: From Theory to Practice. The Oxford Handbook of Governance. In: D. Levi-Faur (ed.) The Oxford Handbook of Governance. Oxford: Oxford University Press, Ch. 32. 
8. Gel'man, V. \& Starodubtsev, A. (2014). Vozmozhnosti i ogranicheniya avtoritarnoi modernizatsii: rossiiskie reformy 2000-kh godov. [Opportunities and Limits of Authoritarian Modernization: Russian Reforms of 2000s]. Russian Polity, no 4, pp. 6-30.

9. Habermas, J. (1984). The Theory of Communicative Action. Vol. I: Reason and the Rationalization of Society. Boston: Beacon. [German, 1981, vol. 1].

10. Habermas, J. (1987). The Theory of Communicative Action. Vol. II: Lifeworld and System. Boston: Beacon. [German, 1981, vol. 2].

11. Krasnov, M.A. \& Obolonsky, A.V. (2003). Vtoraya popytka reformy gosudarstvennoj sluzhby (1997-1998 gg.) [Second Attempt of the Civil Service Reform (1997-1998)]. In: The Civil Service Reform in Russia: History of Reform Attempts from 1992 to 2000. Moscow.: Ves' Mir, pp. 98-156.

12. Kulakova, T.A. (2009). Administrativnaya reforma v respublike Kareliya v 2009 godu [Administrative Reform of 2009 in the Republic of Karelia]. Democracy and Administration, no 2, pp. 16-19.

13. Latour, B. (1987). Science in Action. Cambridge, Mass.: Harvard University Press.

14. Osborne, S. (2006). The New Public Governance? Public Management Review, vol. 8, no 3, pp. 377-387.

15. Osborne, S., Radnor, Z. \& Strokosch K. (2016). Co-Production and the Co-Creation of Value in Public Services: A Suitable Case for Treatment? Public Management Review, vol. 18, no 5, pp. 639-653

16. Petrov, N. \& Titkov, A. (2013). Reiting demokratichnosti regionov Moskovskogo tsentra Karnegi: 10 let v stroyu. [Moscow Carnegie Center's Rating of Democracy in Russian Regions: 10 Years in the Ranks]. Moscow: Carnegie Endowment for International Peace.

17. Rawls, J. (1997). The Idea of Public Reason: Postscript. In: J. Bohman,W. Rehg (eds.), Deliberative Democracy: Essays on Politics and Reason. Cambridge, MA: MIT Press, pp. 131-141.

18. Rosneau, J.N. \& Czempiel, E.-O. (1992). Governance without Government: Order and Change in World Politics. Cambridge University Press.

19. Sabatier P. (ed.) (2007). Theories of policy process. Davis: University of California Press.

20. Sungurov, A.Yu. \& Tinyakov, D.K. (2016). Administrativnaya reforma I ee proekty: byli li koalitsii podderzhki [The Administrative Reform and its Projects: Were There Advocacy Coalitions?]. Social sciences and modernity, no 2, pp. 39-51.

\section{OFFICIAL WEBPAGES:}

1. Monitoring Yugra. Official Webpage of Executive Authorities of Khanty-Mansiiskii Avtonomnyi Okrug. Available at: http://www.monitoring.admhmao.ru/site/(S(ybusjtyrt5boky45q3nylv55))/ reports/OIV_0003_0003/default.aspxc (accessed: 20 December, 2017).

2. Rosstat. Webpage of the Federal Service of National Statistics. Available at: http://www.gks.ru (accessed: 20 December, 2017). 